\title{
Chinese cinema in Spain:
}

\section{An overview through audiovisual translation}

\author{
Helena Casas-Tost and Sara Rovira-Esteva \\ Universitat Autònoma de Barcelona
}

Audiovisual translation has become one of the main means of communication between cultures. Although the number of Chinese films that reach Spanish audiences is rather limited, the cinema is still a very powerful tool in bridging the gap between these two cultures. This paper aims to give an overview of the situation of Chinese cinema in Spain through audiovisual translation. In order to do so, a database of 500 Chinese films translated into Spanish has been created. For each film, different types of information organized into three blocks have been collected: firstly, data regarding the source film in Chinese; secondly, data on the translated film; and finally, information about paratexts related to the film in Chinese, Spanish and English. Through a quantitative and qualitative analysis of our data the main trends in Chinese-Spanish audiovisual translation from the mid-1970s to today are shown. Our results identify the most popular Chinese directors and the main genres and translation modalities. We point out the role of the translator and the importance of mediating languages; and, finally, we highlight the significance of distribution channels, particularly film festivals. This article aims at filling the gap with regard to research in audiovisual translation as an intercultural exchange between China and Spain. 
Keywords: Chinese cinema, Chinese-Spanish translation, audiovisual translation, reception

\section{Introduction}

Cinema forms an important part of culture and, as such, it can become an essential source of a country's soft power. As Su (2010: 317$)$ points out, the film industry in Mainland China is considered "by the Party-state to be an indispensable manifestation of soft power". In the particular case of Mainland China, some authors (Su 2010; Zhou 2015) argue that local film industries have to seek out balances and negotiate their way through the tight control by the authorities that may not always contribute to Chinese cinema's 'go abroad' strategy. ${ }^{1}$ However, as Berry (2008) maintains, Chinese cinema has already become a global brand and has found its place within the ebb and flow of the global cinema market.

In a globalized world, such as the present one, audiovisual translation has become one of the main means of communication between different cultures. In Spain, the cinema has proved to be an extremely powerful tool in bridging the gap between local and foreign cultures. According to the official data provided by the Spanish Ministry of Education,

\footnotetext{
${ }^{1}$ In this article the term Chinese cinema is used to embrace three distinctive but intertwined cinematographies that share a linguistic and cultural background. This comprises all films in Mandarin Chinese and other languages spoken in Mainland China, Hong Kong, and Taiwan, regardless of their origin. It includes all films from these territories, but also those from the Chinese diaspora; as well as transnational productions which result from collaborations with other film industries that are a result of the effects of globalization across the world. In this sense, we can be said to have moved away from the old but interesting debate between the terms Chineselanguage cinemas and Chinese cinema, reviewed by many authors such as Lu and Yeh (2005: 1-12) and more recently by Sun (2016). We also steer clear of the complex discussion about Chineseness, Chinese identity, and nation in relation to cinema, as Beus (2008) already does, since that goes beyond the objectives of this article. For our purposes, we agree with Berry (2008: 297-298), taking Chinese films as those from the abovementioned territories that are in Mandarin (or other Chinese variants), but we also consider films by transnational production companies, and pay attention to the different trends in each of these cinemas.
} 
Culture, and Sport (MECD 2017), only 22.5\% of films shown in cinemas between 2002 and 2016 were Spanish productions and, more significantly, they only achieved an audience of some $16 \%$ (see figure 1). Therefore, audiovisual translation plays a key role in making films from other countries and in other languages available to a Spanish audience.

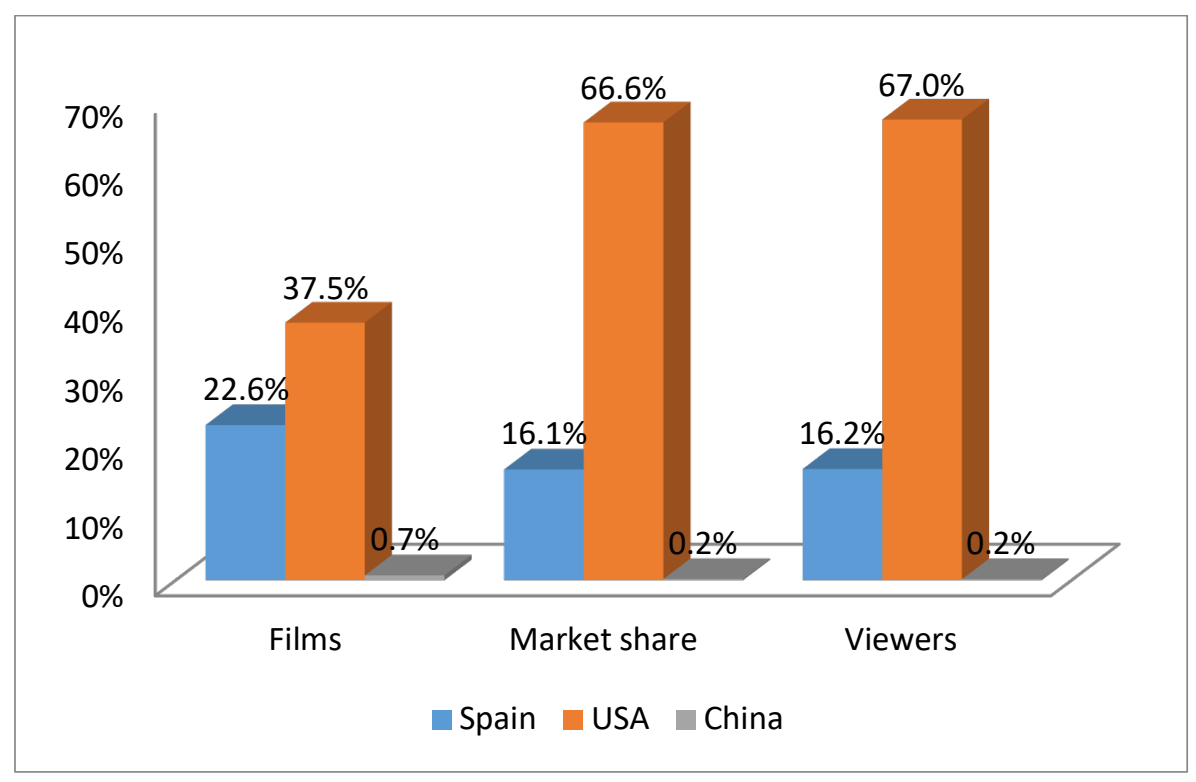

Figure 1 Percentage of films, market share and viewers according to a film's origin (2002-

2016). Data source: Spanish Ministry of Education, Culture, and Sport (MECD 2017) This is also the case for Chinese cinema, even though, as figure 1 shows, the number of Chinese films that reach a Spanish audience is scarce compared to productions coming out of other countries, especially the USA. The latter has a predominant position in terms of market share (up to 67\%), despite the fact that American films represent only $37.5 \%$ of all films shown in Spanish movie theaters. The position of Chinese cinematography is not as relevant, but it is quite similar to that of other Asian film industries, like those from Japan or Korea, in terms of market share. However, this data does not offer a complete picture, since apart from movie theaters, other settings, such as TV, home cinema and, especially, film festivals also play a crucial role in introducing Chinese cinema into Spain.

This paper aims at giving an overview of the current state of affairs of Chinese cinema in Spain through audiovisual translation. The data offered will shed light on what 
films, genres and directors, among other parameters, have reached the Spanish audience, and in what way these have contributed to shaping the image Spaniards have of Chinese culture and society. It will also touch upon some aspects related to the translation process of audiovisual texts specific to this language pair. With this analysis we aim to fill the gap regarding research in audiovisual translation as an intercultural exchange between China and Spain. As Gambier (2009: 17) denounces, “[v]ery few systematic studies have examined the production and reception or the cultural and linguistic impact of audiovisual translation (...).” This article, thus, also aims at making a contribution within descriptive studies of audiovisual translation between Spanish and Chinese, focusing on both the process and the product, from the point of view of its reception.

\section{Methodology}

In order to offer an outline of Chinese cinema in Spain, a database containing Chinese films that have been translated into Peninsular Spanish and Catalan ${ }^{2}$ has been created, and for each film different sorts of information organized into three main blocks has been collected. The first block corresponds to data regarding the source film, comprising the title in Chinese characters and pinyin, the name of the director (also in different formats, including his or her name used internationally, if any), the director's origin (mainly Mainland China, Hong Kong or Taiwan), the genre (such as action, animation, comedy, drama, martial arts, etc.), the year of release, and, finally, the main language(s) used in the film. The second block is devoted to data related to the translation, which includes the translated title, the year(s) of release in Spain, the translator, the target language(s) (Spanish or Catalan), the modality of translation

\footnotetext{
${ }^{2}$ Catalan is a Romance language official in the Autonomous Region of Catalonia with a total population of seven million citizens.
} 
(dubbing or subtitling), and information regarding the film's distributor or the film festival(s) where the film was screened. Finally, the third block collects information about paratexts related to the films both in Chinese and Spanish, but also in other languages with a special emphasis on English, since this usually acts as a mediating language for our language pair. These paratextual elements mainly include information regarding images used to promote the films, film synopsis, reviews published in the general and specialized media, awards, and any literary works on which the films are based (where applicable). That is to say, paratexts represent all those elements that wrap around the main text -in this case films- that are presented to the audience or consumers.

For reasons of space, this paper will only analyze in detail the first two blocks through both a quantitative and qualitative approach. This will allow us to offer an overview of what kind of Chinese films have reached Spanish audiences up to now and what role translation has played in this process, which together with the representation of China on the big screen through the films themselves ultimately contributes to shaping the image of Chinese cinema, and to a certain extent also of Chinese culture in Spain.

The construction of this database is an on-going process, since it is constantly being updated with new entries and new information, as it is not always easy, nor straightforward, to gather all the data for each entry at once. ${ }^{3}$ In order to compile this database, several sources of information have been used, including the webpage of the Spanish Ministry of Education, Culture, and Sport, which contains official data about cinema releases ${ }^{4}$ catalogues of the most significant film festivals in terms of their importance in Spain and as far as Chinese cinema is concerned; specialized websites such as $\mathrm{IMDb}^{5}$ or Filmaffinity; ${ }^{6}$ and, finally, first

\footnotetext{
${ }^{3}$ The data base is open access and available at http://grupsderecerca.uab.cat/txicc/en

${ }^{4}$ See https://icaa.mecd.es/Datos_tecnicos_Peliculas.aspx

${ }^{5}$ See http://www.imdb.com/

${ }^{6}$ See www.filmaffinity.com
} 
hand data directly obtained from informants working for film festivals or CineAsia, ${ }^{7}$ a stakeholder in Asian cinema in Spain. The information gathered was verified by reference to several sources so that it is as accurate as possible, since there are sometimes discrepancies and many gaps, especially with regards to films covered by the first decades of our database.

In the process of building this database, we have encountered some methodological difficulties that are worth mentioning. Firstly, it has not always been possible to obtain reliable and complete data about the channels of distribution of Chinese films (mainly cinema, film festivals or home cinema) and the year they were shown in Spain through each of these channels. Whenever the same film was shown on different channels, all the different years of release have been registered, with the earliest being chosen as a comparison with the original release date.

Secondly, information related to the translation process proved to be the most difficult to gather. This fundamentally entails the name of the translator and whether the translation was carried out directly from Chinese or through a mediating language, such as English (which apparently is the most common practice, especially at film festivals). The information about the modality of translation, dubbing or subtitling, is only clear in the case of film festivals, but this information is not always available in the case of movie theaters. This is also applicable to the year of release, while this may be transparent for film festivals and similar events, this information is not always provided by other distribution channels, including movie theaters and home cinema.

Thirdly, in some cases, different titles in Spanish have been registered for the same original film in Chinese, because different translations have been made for different purposes over the years. The database collects all the different versions.

\footnotetext{
${ }^{7}$ See http://www.cineasiaonline.com/
} 
Fourthly, as for the origin of the films, two different pieces of information have been taken into account: the origin of the filmmaker, which is rather straightforward, and the country as registered in the distribution channels. However, this can sometimes be confusing, as Beus (2008: 306) decries using the example of Wang Xiaoshuai's film二弟 (Èr Dì Drifters), since it was classified as Taiwanese at the Hawaii International Film Festival, Taiwanese/Chinese in Cannes and, finally, as Hongkongese at the Greek Thessaloniki International Film Festival.

Fifthly, films tend to be classified in more than one genre and sometimes it is difficult to choose only one label to describe them, either because there is no clear-cut division between categories, such as martial arts and action films or because, for example, a martial arts movie can be targeted at children and also be tagged as a children's movie or comedy. In these cases, the first label used in specialized sources has been the one chosen for conducting the analysis.

In sixth place, we wanted to include information about the films' original language(s) and realized that there is a non-negligible percentage of them that use more than one, not only the so-called Chinese dialects, but also other languages spoken in China as well as foreign languages. Therefore, all the different languages have been recorded in detail, but some categories were later merged to facilitate data analysis. For instance, whenever Standard Chinese was used together with dialects other than Cantonese, such as Hakka or Hokkien, the language was categorized as Standard Chinese and dialect.

Finally, it has not been possible to gather data about the number of viewers and the total revenue for all the films in our database, since this information is only available for the films included on the Ministry's website, which, unfortunately, are only those which were shown in cinemas. Taking into account that we are studying a 44-year span, revenue has not 
been considered to be a comparable measure across time, and instead the size of the audience has been taken as a reference in gauging Spanish interest in Chinese films.

\section{Results}

At the time of writing this paper, our database comprised a total of 500 Chinese films shown in Spain from the year 1973 until September 2017, when the first specialized film festival exclusively devoted to Chinese cinema (Lychee Film Festival $)^{8}$ was held. The first Chinese movie screened in Spain, only two years after its release in Taiwan and Hong Kong in 1971, was 獨臂拳王 (Dú Bì Quánwáng - One Armed Boxer) by Wang Yu, translated into Spanish as El luchador manco.

Since data analysis is complex because the different factors involved are intertwined, for the sake of clarity, results will be presented in the following sections: evolution (3.1), genres (3.2), directors (3.3), origin (3.4), distribution channels (3.5), audience (3.6), languages (3.7), and translation (3.8).

\subsection{Evolution}

Berry (2008: 297) identifies different export moments for Chinese cinema, the first dating back to the 1970s at the hand of Bruce Lee's martial arts films. However, the turnaround of Chinese cinema as a global and culturally defined national brand originated with the breakthrough screening of 黄土地 (Huáng Tǔdì- Yellow Earth / Tierra amarilla) at the 1985 Hong Kong International Film Festival, not only launching "the Fifth Generation of Chinese

\footnotetext{
${ }^{8}$ See http://www.lycheefilmfestival.com/ca/film/
} 
films and filmmakers as an art-house line for the 'Chinese cinema' brand" (ibid.), but also opening the door for the works of Taiwan's New Cinema directors, such as Edward Yang and Hou Hsiao-hsien, along with Hongkongese action films associated with John Woo.

This also applies to Spain, even though from a chronological point of view no clear trend can be observed for the evolution of the number of films reaching Spanish audiences. As shown in figure 2, there is a peak of films shown in 2011, with a total of 42 Chinese movies, whereas there are only 13 which correspond to the following year. Nonetheless, generally speaking, there is a growing tendency for a rise in the number of Chinese films shown in Spain, especially after the beginning of the new millennium. The particular peak of 2011 was due to the fact that, on the one hand, the $59^{\text {th }}$ edition of the most important film festival in Spain — the San Sebastian Film Festival— included a thematic retrospective devoted to Chinese cinema and, on the other, the Casa Asia Film Week and its Hong Kong film week were both especially abundant in Chinese films. After that year, and in particular after 2012, the number decreased notably. Codó (2017: 121) points out that the economic crisis and the increase in government taxes on cultural events (including cinema) in Spain account for the decline in the number of viewers going to movie theaters, which has been even more acute in the case of Asian films. 


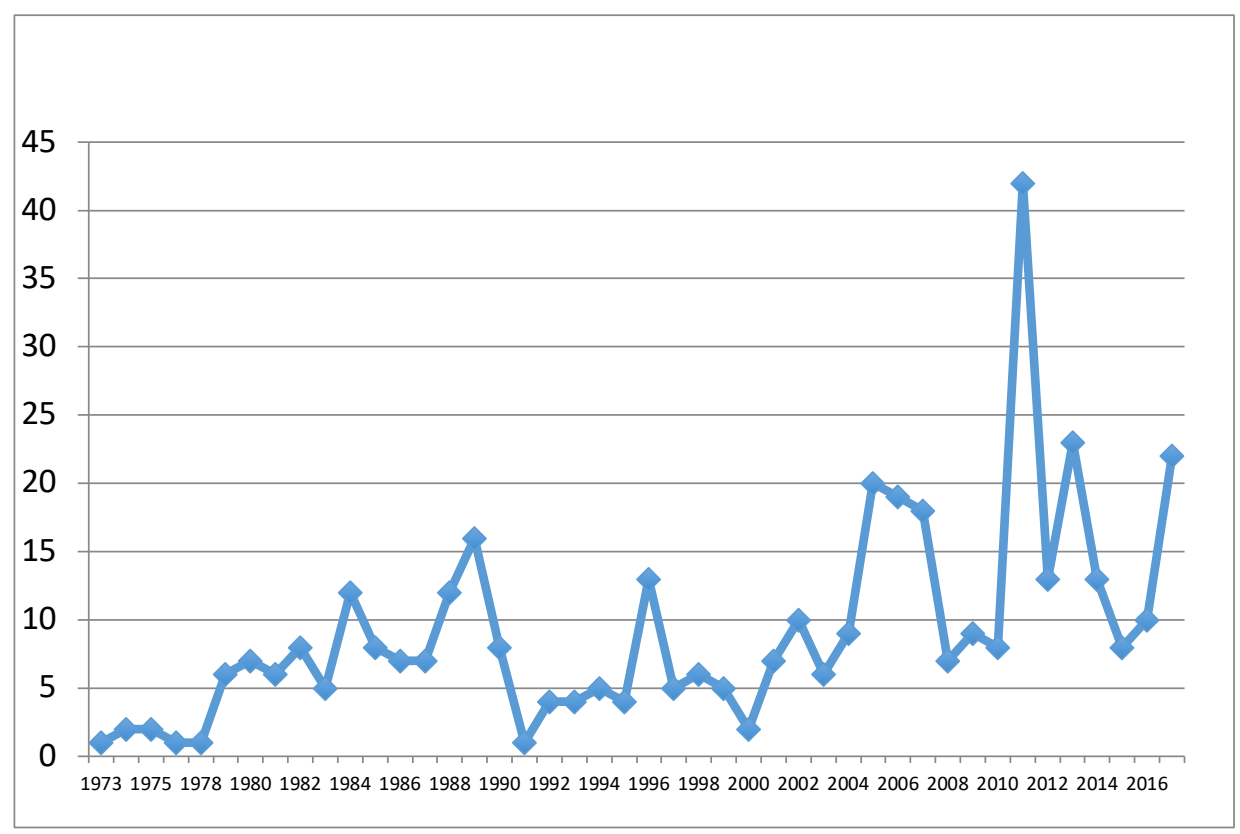

Figure 2 Evolution of Chinese film releases in Spain

In the past four decades, the reduction of the time span between the original year of a Chinese film's release and that of its release in Spain is an obvious and positive development, as shown in figure 3 . While, until the year 2000 , the difference was over six years, in the last decade the average has dropped to only one year. Advances in technology and communication media, as well as closer economic and intercultural exchanges between China and Spain have speeded up the import and access to cultural products from one country or the other. We wonder if China's marketization process of the film sector, starting in 1998 to meet the goal set by the Chinese Communist Party's $15^{\text {th }}$ National Congress to help China advance into the $21^{\text {st }}$ century ( $\left.\mathrm{Su} 2010: 318\right)$, has also had any impact on the introduction of Chinese films into the Spanish market.

However, it must also be noted that older films from the 1970s and 1980s are still shown in retrospectives nowadays, especially in film festivals, such as the Asian Summer Film Festival and the Lychee Film Festival, where movies such as 猩猩王 (Xīngxing Wáng Goliathon / El hombre de Pekín) by Ho Meng-hua from 1977 and 侠女 (Xiá Nü - A touch of zen / Un toque de zen) by King Hu from 1970 were shown in 2017. 


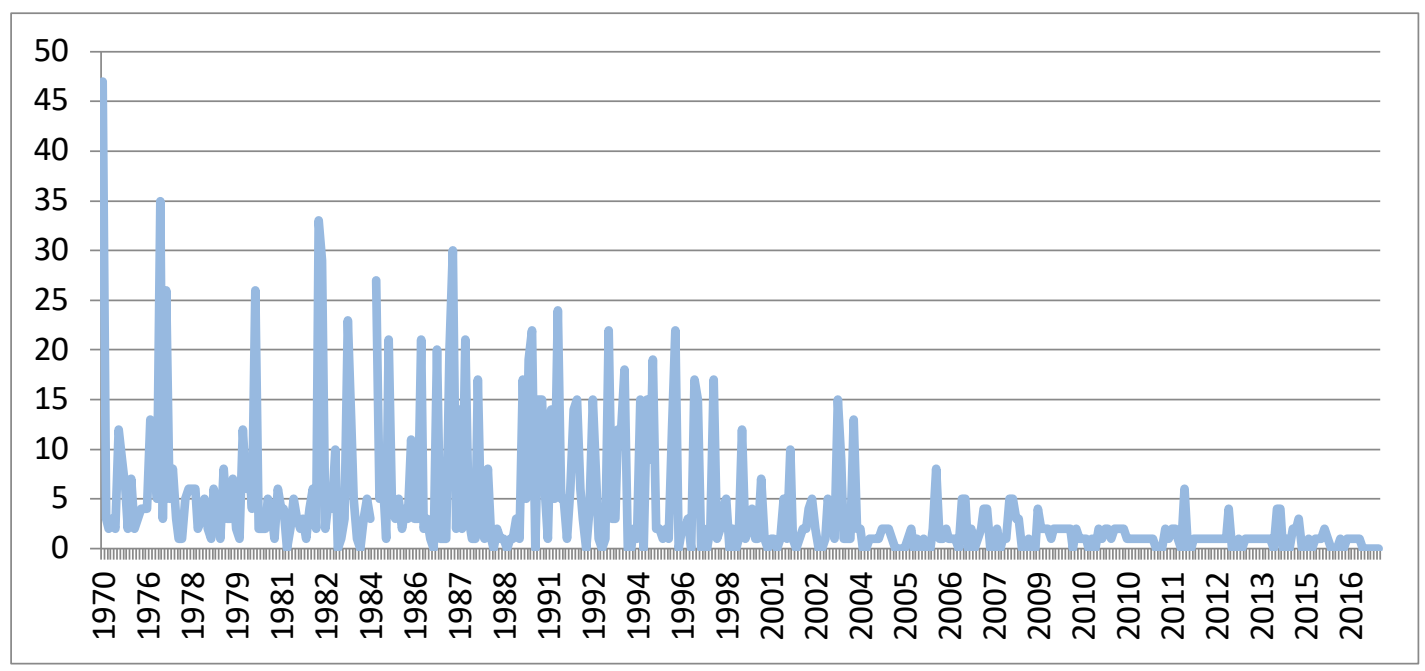

Figure 3 Time-span between release in China and in Spain

\subsection{Genres}

As stated above, the first Chinese film released in Spain was a martial arts movie. It comes as no surprise, as this genre has had a strong presence in Spain from the 1970s up to the present day. In fact, the recently created Lychee Film Festival devoted its first edition in 2017 to this genre. Moreover, that very same year, China was the guest country at the $14^{\text {th }}$ edition of the Asian Summer Film Festival, with a retrospective of female martial arts stars featured in Chinese action films. ${ }^{9}$ Altogether this reveals that martial arts, including new productions as well as older ones, draw the attention of film festivals programmers.

Figure 4 shows that in our database martial arts and action films represent half of the movies, constituting almost all the films imported up to the 1980s. Actually, Spain seems to be no exception to the general trend, since according to $\mathrm{Su}(2010: 320)$ oriental exotic martial arts movies have long been present in the Western film market since the heyday of Bruce Lee, while from the 1990s onwards, with the debut of director John Woo and martial arts movie stars - such as Jackie Chan, Chow Yun Fat and Jet Li- in Hollywood, Chinese movies have

\footnotetext{
${ }^{9}$ See http://cinemaoriental.com/en/retrospectiva-i-llibre-kung-fu-girls/
} 
exerted an increasing influence on the Western film market. She claims that thanks to the success of 卧虎藏龙 (Wò Hǔ Cáng Lóng - Crouching Tiger, Hidden Dragon / Tigre y dragón) in 2000, Mainland China's top-notch directors began to realize the selling point that martial arts movies represented and dedicated themselves to the production of this genre. Berry (2008: 316) argues the main revenue for these kinds of films comes from North America, followed by Europe and Japan, which clearly demonstrates it is an export-led phenomenon, and our data confirms this trend in the case of Spain.

After martial arts and action films together, the most predominant genre is drama, with $28 \%$ of the entries belonging to this category. Such films started being introduced in Spain in the mid-1980s and have been very significant ever since, especially over the last 15 years, when this genre has become the most abundant in comparison with the others.

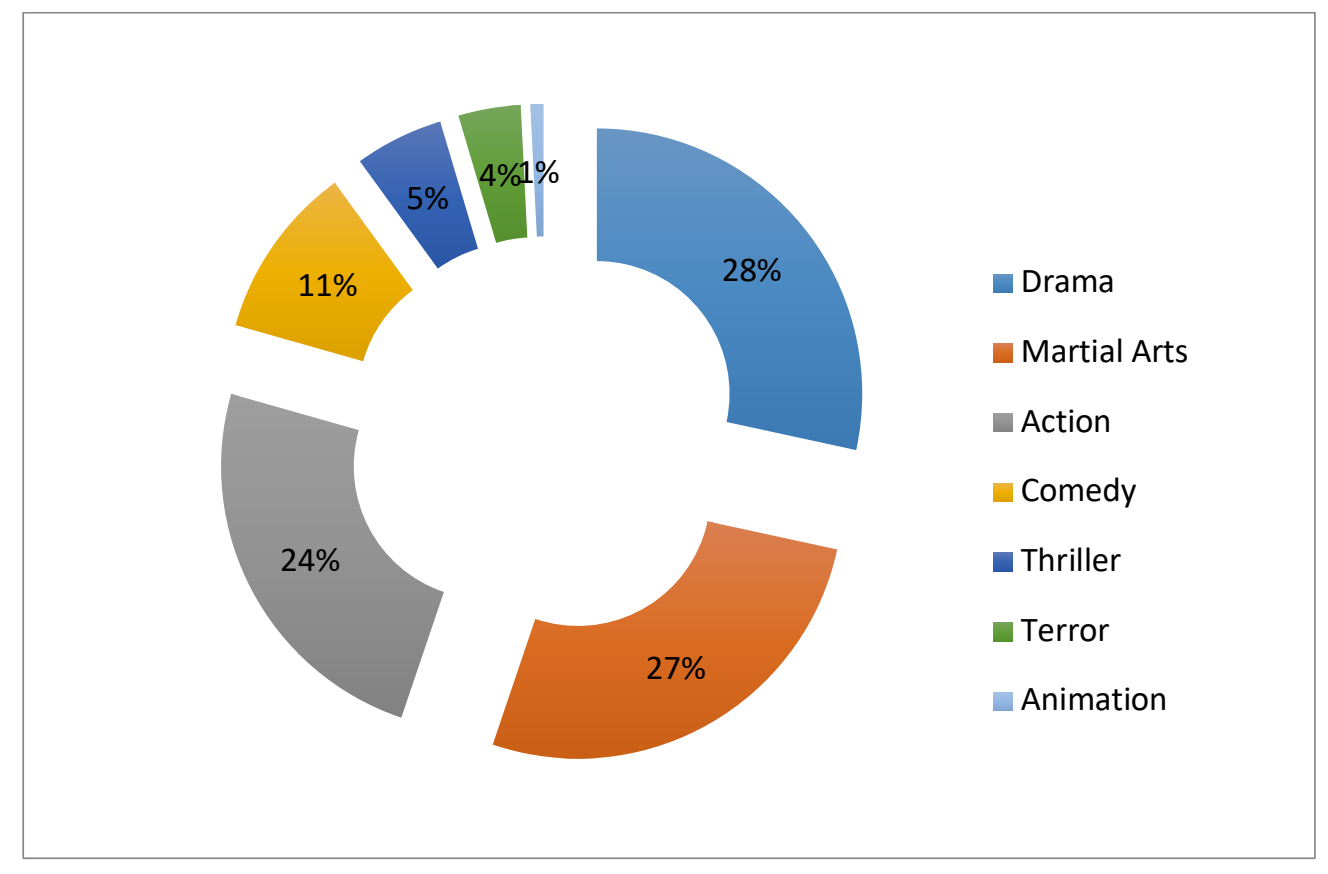

Figure 4 Chinese movies released in Spain according to genre

The least significant genre in quantitative terms is animation, with only four films out of 500 (1\%). Chinese animation films entered Spain very recently, with 麦兒故事 (Màidōu Gùshi My Life as McDull) in 2002, shown at three different film festivals. In fact, all the aforementioned animation films have only been released through films festivals, except for 青 
蛙王国 (Qīngwā Wángguó - Frog Kingdom / El reino de las ranas) that was also released in cinemas. Therefore, Chinese animation does not seem to have attracted the attention of Spanish audiences yet. For instance, 捉妖记 (Zhuō Yāo Jì - Monster Hunt), which became the highest-grossing film in China in 2015, with more than 370 million dollars in revenue, was not shown in mainstream movie theaters in Spain. It was just shown at the $13^{\text {th }}$ edition of the Asian Summer Film Festival in Vic (a town with only 43,000 inhabitants approximately) and again six months later at the presentation of the $14^{\text {th }}$ edition, devoted to China.

\subsection{Directors}

So far, our database has recorded a total of 279 different directors. A little bit more than half of them originally come from Hong Kong, while Mainlanders represent 25\%, and Taiwanese filmmakers account for $21 \%$. There is only $1 \%$ that corresponds to directors with a Chinese background coming from countries such as Singapore, the UK, the USA, and Korea.

However, if one takes a closer look at the directors' works, it soon becomes clear that a handful of them, accounting for only $7 \%$, have directed as many as $35 \%$ of all the films seen in Spain. Zhang Yimou being the most prolific, with a total of 20 titles. Therefore, this $7 \%$ of directors is potentially much more influential than the rest, and their filmic representations of China may sway the attitudes of Spanish audiences in relation to Chinese culture, in general, and cinema, in particular. As shown in table 1, these directors are mostly male and come principally from Hong Kong (almost 70\%), while Mainlanders account for $20 \%$ and the remaining $10 \%$ are from Taiwan.

However, a greater number of films does not always correlate to a greater number of viewers. According to the data available, adding up all the viewers of the films of all these directors, only three have reached more than one million viewers: Zhang Yimou $(2,539,805)$, 
Ang Lee $(2,246,855)$, and Yuen Woo-ping $(1,343,158)$. These last two directors only have five Chinese films released in Spain, which represent four times less than Zhang Yimou. At the same time, it is also worth mentioning that names such Edward Yang or King Hu are not on this list, while they are renowned throughout the world.

Table 1 Most prolific Chinese directors seen in Spain

\begin{tabular}{|l|l|}
\hline Directors & $\begin{array}{l}\text { Number of films } \\
\text { released in Spain }\end{array}$ \\
\hline Zhang Yimou & 20 \\
\hline Sammo Hung & 13 \\
\hline Tsui Hark & 13 \\
\hline Ann Hui & 11 \\
\hline Jackie Chan & 11 \\
\hline John Woo & 11 \\
\hline Johnnie To & 11 \\
\hline Wong Kar-Wai & 10 \\
\hline Chen Kaige & 7 \\
\hline Godfrey Ho & 7 \\
\hline Jia Zhangke & 7 \\
\hline Joseph Velasco & 7 \\
\hline Lee Tso-nam & 7 \\
\hline Ringo Lam & 7 \\
\hline Hou Hsiao-hsien & \\
\hline Tony Ching & 7 \\
\hline
\end{tabular}




\begin{tabular}{|l|l|}
\hline Ang Lee & 5 \\
\hline Corey Yuen & 5 \\
\hline Yuen Woo-ping & 5 \\
\hline
\end{tabular}

\subsection{Origin}

During the 15 years following the first screening of a Chinese film in Spain, all movies came from Hong Kong and Taiwan, since from the early 1950s to late 1970s, Chinese cinema in the People's Republic of China (PRC) was regarded as a tool for Communist propaganda (Zhu, 2001) and, thus, intended for the local market. It was not until 1987 that the first film from Mainland China was shown in Spain. It was a martial arts film, entitled 武当 (Wǔdāng - The Undaunted Wudang / La secta del kung fu), directed by Sun Sha. Ever since, as a result of China's Four Modernizations, cinematic modernization in the PRC, and the arrival of New Wave cinema, the percentage of imported films by directors from Mainland China has been growing. These films belong to the so-called Fifth Generation, led by Zhang Yimou and Chen Kaige. Two of the four most emblematic films of the Chinese New Wave, Chen Kaige's 黄土 地 (Huáng Tǔdì- Yellow Earth / Tierra amarilla) (1985) and Tian Zhuangzhuang’s 盗马贼 (Dào Mă Zéi - Horse Thief / El ladrón de caballos) (1986) were shown in Spanish movie theaters in 1989 and 1990, respectively. However, those that were more warmly received by audiences of the time were two films by Zhang Yimou: 红高粱 (Hónggāoliáng - Red Sorghum / Sorgo rojo) (1987) and 菊豆 (Jú Dòu - Ju Dou / Ju Dou: semilla del crisantemo) (1990), with more than 120,000 viewers each. As in other Western countries (Berry 2008: 297), that represented a turning point, in which Chinese dramas started to be regularly imported into Spain and welcomed by audiences and critics alike. From then on, movies by Mainland China filmmakers started to redress the balance in comparison with those from 
Hong Kong and, at the same time, rapidly surpassed the number of films by Taiwanese directors.

Despite the fact that the term "transnational Chinese cinema" is now commonly used to indicate the boundary-crossing nature of the cinemas from all three regions in terms of financing, production, distribution and marketing" (Beus 2008: 308), there is still a clear-cut division among the cinemas of the three regions in terms of imported genres. Directors whose work has reached Spain from Mainland China have mostly created dramas, while filmmakers from Hong Kong and, to a lesser degree, from Taiwan, have made martial arts and action films. Moreover, all horror movies that have been shown in Spain come from Hong Kong, except for one, directed by a Taiwanese filmmaker (see figure 5).

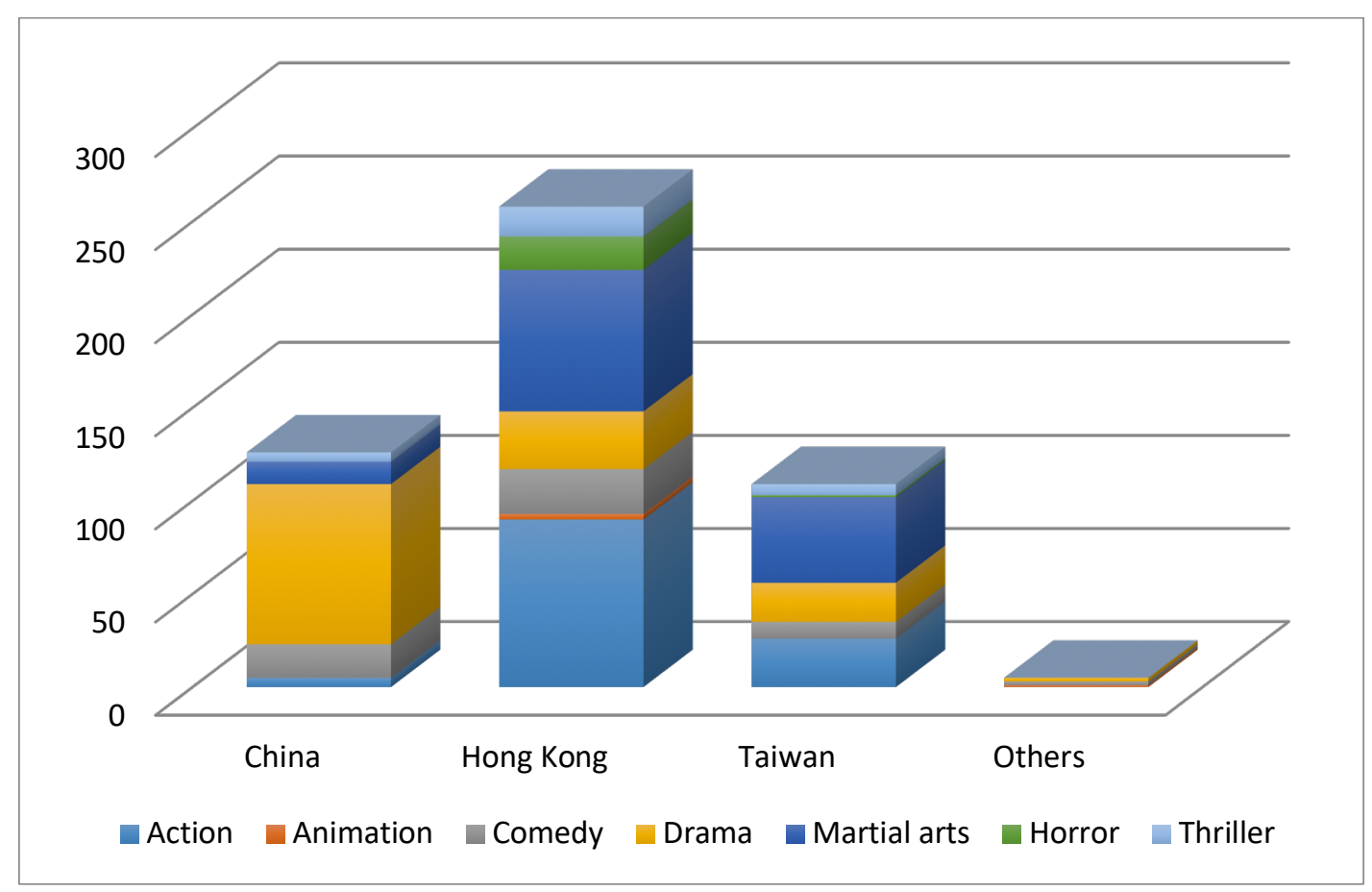

Figure 5 Number of films screened in Spain according to genre and directors' origin

\subsection{Distribution channels}


If one looks at the way Chinese films have been distributed in Spain, one realizes the importance in the introduction of Chinese films of film festivals and film cycles in places like film archives or Confucius Institutes. Our data reveals that there are slightly more films that have reached Spanish audiences through these channels (42\%) than through movie theaters (28\%), while around $13 \%$ have been shown in both screening slots. Moreover, films shown at film festivals are often released sooner, and when they arrive through both channels they are usually shown first at film festivals rather than in cinemas. For example, all the films from our database originally released in 2017 were offered to Spanish audiences the same year thanks to film festivals, more precisely the generic San Sebastian Film Festival and the specialized Summer Asian Film Festival in Vic.

Finally, another important distribution channel has been VHS, DVDs and, more recently, other sorts of home cinema. This is even the case for new releases, which reach the market directly in DVD format, as pay per view products or are readily available through peer-to-peer networks, instead of being first screened in movie theaters or film festivals. Actually, as Gambier (2009: 20) puts it, "[t]here is more downloading of films everyday than viewers in cinema theatres".

Distribution channels depend greatly on the film genre and the director's profile. For example, in the case of Zhang Yimou's films, 18 out of 20 of his films have arrived through cinemas, while six have also been shown in other screening slots; and only 三枪拍案惊奇 (Sān Qiāng Pāi'àn Jīngqí - A Woman, a Gun and a Noodle Shop / Una mujer, una pistola y una tienda de fideos chinos), that departs from the rural dramas this director is well-known for in Spain, was shown at a film festival before being released in movie theaters.

The most important Spanish film festivals are in San Sebastian, Sitges, Malaga, Valladolid, and Gijon. Although they are all generalist in terms of the film's origin, not all of them have the same tradition, nor have they included the same volume of Chinese films in 
their programs throughout their history. Up to now, San Sebastian leads the ranking with a total of 59 Chinese films screened since the first Chinese film was shown there in 1987, namely Edward Yang’s 恐怖分子 (Kŏngbù Fènž - Terrorizers). The Sitges International Film Festival, specializing in fantasy and horror films, has shown 31 Chinese films in its 50year history, starting from 1987 with 倩女幽魂 (Qiàn Nü Yōu Hún - A Chinese Ghost Story / Una historia china de fantasmas). Malaga's Fantasy Film Festival, with a section devoted to Asian films, has already shown nine Chinese films in its 20-year history. Valladolid International Film Festival, that has been held annually since 1956 and is presently regarded as one of the most important in the field of independent and amateur films, has screened eight Chinese films altogether. Gijon International Film Festival, dating back to 1963 and devoted to children films, has screened six Chinese movies.

The Filmoteca de Catalunya, a film archive founded in 1981 in Barcelona aimed at the preservation of film and the dissemination of audiovisual and film culture, has screened eight Chinese films so far. To our knowledge, the Filmoteca de Andalucia, a similar film archive founded in 1987 in the autonomous region of Andalucia, has only screened four Chinese films. Although these government-run cinemas are aimed at the general public, their film selection is neither mainstream nor commercially driven. In this context, they have organized cycles devoted to certain cinemas, such as Taiwanese cinema in 2002 and 2017.

The first specialized Asian film festival in Spain we are aware of is the Muestra de Cine Asiático de Barcelona, which started in 1999, followed by the Barcelona Asian Film Festival (BAFF), superseded in 2011 by the Casa Asia Film Festival (CAFF), later called Casa Asia Film Week (CAFW) and, currently embodied by the Asian Film Festival (AFFBCN). This film festival started as a private enterprise, but now it is run by Casa Asia, a government funded institution set up to bolster knowledge of, and increase dialogue about, Asia in Spain. According to our records, 64 films have been screened in the context of this 
festival in the almost 20 years of its history. Another important Asian film festival is that held in Vic, which has already screened more than 60 Chinese titles. The brand new Lychee Film Festival is also worth mentioning, because it is the only one exclusively devoted to Chinese cinema in Spain. In its first edition held in September 2017, it showed 13 Chinese films. Finally, in 2017, the Confucius Institute in Barcelona also set up Chinese cinema cycles to be held on a regular basis, with the collaboration of Cine Asia. It showed a total of nine films in its first year.

Beus (2008: 312) claims that if we are familiar with the big names in Chinese cinema it is because they have all had their works available through a highly selective distribution system in the West or have become known through international film festivals. Therefore, we must also bear in mind that the Spanish cinematic market is no doubt influenced by the Western one; i.e., top international film festivals, such as those from Cannes, Venice or Berlin, in the case of Europe, or the Academy Awards in the USA.

\subsection{The audience}

As is the case in other Western countries ( $\mathrm{Su} 2010: 320)$, the most successful films in terms of audience in Spain have all been martial arts films. These are films that are not mainly targeted at their local audience, but aimed at the whole world as part of global entertainment cinema. As Berry (2008: 316) puts it, they constitute "an export-led phenomenon, and it often drives a tourist fantasy of Chinese national culture.”

According to records from the Spanish Ministry of Education, Culture, and Sport (which only takes into account movie theater viewers), the Chinese film with the biggest audience has been Luo Wei’s 唐山大兄 (Tángshān Dàxiōng - The Big Boss / Karate a muerte en Bangkok). It was screened in Spain back in 1981 and at that time the audience 
registered was $2,034,752$ people, which is really remarkable. It is also noteworthy that 14 out of the top-15, in terms of audience, fall into the category of martial arts, mostly to films from the 1970s and early 1980s. Among the fifteen films with the highest audience, only three were screened in the new millennium (see table 2). The first being the Oscar-winning of 卧虎藏龙 (Wò Hǔ Cáng Lóng - Crouching Tiger, Hidden Dragon / Tigre y dragón) (2001) by Ang Lee, which at the time broke box-office records in China (Lu and Yeh 2005: 20). It was the biggest foreign-language blockbuster in the USA (Codó 2009: 8) and was seen by 1,557,786 people in Spain. This film was followed by the more recently released 长城 (Chángchéng The Great Wall/ La Gran Muralla) (2017), with 736,596 viewers. Finally, 英雄 (Yīngxióng Hero) (2003), despite being an Academy Awards nominee for Best Foreign Language Film in 2004 and having set new box-office sales records in China, only had an audience of 314,986 viewers in Spanish cinemas.

Editor's note

Table 2 Ranking of top-15 Chinese films in terms of audience in Spanish cinemas

\begin{tabular}{|l|l|l|}
\hline Films & Release year in & Viewers \\
\hline Karate a muerte en Bangkok) & 1981 & $2,034,752$ \\
\hline $\begin{array}{l}\text { 唐山龙过江 (Měng Lóng Guò Jiāng - Way of the } \\
\text { Dragon / El furor del dragón) }\end{array}$ & 1975 & $1,823,433$ \\
\hline 独臂拳王 (Dú Bì Quánwáng - One Armed & 1973 & $1,568,956$ \\
Boxer / El luchador manco) & & \\
\hline 卧虎藏龙 (Wò Hù Cáng Lóng - Crouching & 2001 & $1,557,786$ \\
Tiger, Hidden Dragon / Tigre y dragón) & & \\
\hline
\end{tabular}




\begin{tabular}{|c|c|c|}
\hline $\begin{array}{l}\text { 精武门 (Jīng Wǔ Mén - Fist of Fury / Furia } \\
\text { oriental) }\end{array}$ & 1974 & $1,374,881$ \\
\hline $\begin{array}{l}\text { 蛇形フ手 (Shéxíng Diāo Shǒu - Snake in the } \\
\text { Eagle's Shadow / La serpiente a la sombra del } \\
\text { águila) }\end{array}$ & 1979 & 851,126 \\
\hline $\begin{array}{l}\text { 新精武门 (Xīn Jīng Wǔ Mén - New Fist of Fury } \\
\text { / El desafio de Bruce Lee) }\end{array}$ & 1980 & 836,502 \\
\hline $\begin{array}{l}\text { 长城 (Chángchéng - The Great Wall/ La Gran } \\
\text { Muralla) }\end{array}$ & 2017 & 736,596 \\
\hline $\begin{array}{l}\text { 龙争虎斗精武魂 (Lóngzhēng-Hǔdòu Jīng Wǔ } \\
\text { Hún - Black Dragon's Revenge / ¿Quién mató a } \\
\text { Bruce Lee?) }\end{array}$ & 1979 & 554,357 \\
\hline $\begin{array}{l}\text { 南北醉拳 (Nán Běi Zuì Quán - Dance of the } \\
\text { Drunk Mantis / La danza de la pantera } \\
\text { borracha) }\end{array}$ & 1980 & 492,032 \\
\hline $\begin{array}{l}\text { 香港小教父 (Xiānggăng Xiăo Jiàofù - Little } \\
\text { Godfather from Hong Kong / El pequeño } \\
\text { padrino de Hong Kong) }\end{array}$ & 1976 & 472,222 \\
\hline $\begin{array}{l}\text { 半厅八两 (Bàn Jīn Bā Liăng - Mr. Boo: The } \\
\text { Private Eyes / Mister Boo (El intrépido)) }\end{array}$ & 1979 & 458,257 \\
\hline $\begin{array}{l}\text { 盲拳鬼手 (Máng Quán Gữ Shŏu - Blind Fist of } \\
\text { Bruce / El puño ciego de Bruce) }\end{array}$ & 1981 & 390,467 \\
\hline
\end{tabular}




\begin{tabular}{|l|l|l|}
\hline 广东小老虎 (Guăngdōng Xiăo Lăohǔ - Master & 1982 & 317,833 \\
with Cracked Fingers / La furia de Jackie) & & 314,985 \\
\hline 英雄 (Yīngxióng - Hero) & 2003 & \\
\hline
\end{tabular}

According to official data about moviegoers, the average number of viewers per Chinese film in Spanish movie theaters is 172,392 . Only $23 \%$ of the films in our database have attracted bigger audiences, while the majority achieve far below the average. The case of Tian Zhuangzhuang’s 盗马贼 (Dào Mă Zéi - Horse Thief / El ladrón de caballos) (1986), considered to be a cinematic masterpiece, is especially striking, as it only registered 11 viewers according to the data provided by the Spanish government.

After some boom years, Garcelán (2015: 99-100) deplores the fact that in the past few years Asian cinema has been undergoing a kind of crisis in terms of the amount of films that have reached Spanish cinemas. However, it is even more worrying in terms of audience, since that has dropped dramatically. This is even the case for films by well-known Chinese directors, such as Wong Kar-Wai, with 一代宗师 (Yí Dài Zōngshī - The Grandmaster) in 2013, which attracted less than 30,000 viewers or Jia Zhangke’s award-winning 天注定 (Tiān Zhùdìng - A Touch of Sin / Un toque de violencia), with less than 18,000 people seeing it in 2013. However, we must bear in mind that our database does not include figures related to audiences attending film festivals, on the one hand, nor VHS or DVD sales, and, more recently, pay per view TV or Internet film consumption, on the other, because this kind of information is not readily available and is almost impossible to trace.

Codó (2009: 18-19) maintains that Asian cinema, including Chinese cinema, has two kinds of audience in Spain: an arty or cool one that enjoys watching non-mainstream films at festivals, and a freak one, fond of genre-specific films, such as martial arts, that seeks them out on the Internet and in alternative channels and formats, such as DVD, video-streaming, 
video on demand, podcasting or portable players. Unfortunately, there is no official data as to how many people watch Chinese films through these alternative sources. In the same vein, Berry (2008: 314-316) distinguishes two product lines under the banner of Chinese cinema. Firstly, the global cinemascape embodied by international film festivals, "often funded by transborder investment sources and seen by relatively few people within their territories of production as well as specialist audiences that gathers at film festivals around the world". Secondly, we find martial arts blockbusters, which are seen by mainstream audiences around the world, including in their territories of production, and that are part of the transborder flow that is global entertainment cinema. In this sense, Ang Lee’s 卧虎藏龙 (Wò Hǔ Cáng Lóng Crouching Tiger, Hidden Dragon / Tigre y dragón) is the best example of a martial arts blockbuster moving away from the niche market and into the multiplex theaters, and a quintessential example of global cinema.

Berry (2008: 314) believes that Chinese cinemas correspond to a variety of different markets defined according to taste structures that correspond to class, culture and infrastructure. Although it is also our contention that these quite separate cinemas appeal to distinctive audience segments, according to our data, this distinction might be starting to blur, since at least at Spanish film festivals martial arts films have an outstanding position.

Beyond the quantitative analysis, we must reflect upon the image Spaniards build up of Chinese culture through these films. From our point of view, arty or non-mainstream films, represented both by the Fifth and Sixth generation of directors differ greatly in their portrayal of Chinese culture compared to traditional martial arts movies.

One the one hand, the China reflected by the Fifth generation is the result of a rather introspective root-seeking movement in order "to understand how Chinese culture came into being and what the origins of Chineseness are" somehow engaging "itself in an anthropological observation of China and Chinese" (Zhu 2001: 458). The directors of the 
Sixth generation turned their focus towards contemporary China's inner tensions and contradictions, which no doubt depict a less idyllic image of China. One the other hand, as $\mathrm{Su}$ (2010: 320-321) points out, the fundamental strategy that contemporary martial arts films employ "is to draw on traditional Chinese cultural and historical resources and incorporate Hollywood techniques". She further explains, they "use Chinese martial arts as their biggest selling point, featuring dazzling, skillful fighting scenes" but, at the same time "[t]hey also highlight traditional Chinese cultural values like brotherhood, family ties, personal perseverance, and loyalty". Both the costumes and the magnificent settings tend to offer a highly exotic image of China. This product of intercultural encounter (combining Chinese martial arts and aesthetics with Hollywood cinematic techniques) has proved to be a commercial success. Moreover, when it comes to censorship in China, both Hollywood and China's domestic filmmakers believe that having a film set in an ancient world is politically safe, financially less risky and more commercially successful ( $\mathrm{Su} 2010: 321)$.

Further research is needed to draw a clearer picture of Chinese cinema genres in relation to distribution channels and audience profile. Cinema and festival-goers used to be young, educated, and computer-literate as compared to TV viewers, that more often included children and elderly people. But new distribution channels are changing viewers' profiles. Moreover, it seems that martial arts movies and stars like Jackie Chan and Jet Li have moved from being thought of as niche movies to becoming part of the mainstream of popular culture. Despite being considered better representatives of Chinese cinema by specialists and academics, the works of internationally awarded well-known Chinese directors seem to have a box office problem and are consequently considered art or independent films aimed at a niche market rather than a mass market audience.

\subsection{Languages}


Mandarin is still the predominant language of the films that have reached Spain, despite the fact that more than half of the total have been directed by Hong Kong filmmakers. The use of Mandarin-only accounts for $40 \%$ of the cases, followed by Cantonese-only (30\%), which gives an idea of its importance. Mandarin often shares the scene with other languages $(24 \%)$, with a special relevance for Cantonese (9\%). Cantonese is, thus, present in $44 \%$ of cases. It is widely used in films in Hong Kong, although Mandarin is still an important language there. As Berry (2008: 309) explains:

Hong Kong cinema was not aimed only at the Hong Kong market. In fact, its main market was diasporic Chinese, for whom Chinese culture formed a site of nostalgia distinct from the societies they lived in. As a result, these films were also made in languages other than Cantonese, including Mandarin and various Hokkienese languages.

\subsection{Translation}

As stated at the beginning of this paper, one of the major difficulties in gathering information for our database has been related to the translation of films. In as many as $91 \%$ of the cases, the name of the translator is unknown. For the remaining 9\%, we know that at least half the translators recorded do not translate directly from Chinese, but from a mediating language, mostly English. In fact, thanks to first-hand information and personal contacts, we can guarantee that only $8 \%$ of the cases are direct translations from Chinese.

As for the languages into which the films have been translated, Spanish is the predominant one $(89 \%)$, while only $9 \%$ have been translated into Catalan and the remaining $2 \%$ have been translated into both languages. 
The presence of Catalan as a target language for Chinese films in Spain is mainly due to two reasons. First, because the public television of Catalonia is a key agent in the distribution of films on TV and foreign films are translated and broadcast in Catalan. Second, Catalonia can be considered an Asian cinematic hub in Spain. The Summer Asian Film Festival from Vic is one of the major (if not the most important) film festivals in Spain devoted to Asian cinema. Even though it is held in a small town in central Catalonia, it has become a reference festival for Spanish lovers of Asian cinema. This festival has grown in importance over its fourteen-year history and has proved capable of showing high quality films and distributing premieres in Spain. Such as the case of 捉妖记 (Zhuō Yāo Jì Monster Hunt) in 2016 or 喊山 (Hăn Shān - Mountain Cry) in 2017, or even European premieres such as 决战食神 (Juézhàn Shí Shén - Cook up a storm) in 2017. In this festival, films are subtitled mainly into Catalan and English, only seldom into Spanish if the film has been previously translated into Spanish. This also applies to films shown at the Filmoteca de Catalunya.

The fact that Chinese films are mostly not directly translated into Spanish or Catalan is due mainly to the following interrelated reasons. Firstly, there is still a relatively small number of Chinese-Spanish professional translators in Spain. Secondly, since film producers often provide the original soundtrack script with English subtitles, distributors tend to hire English-Spanish translators as a more cost-effective option.

After all, the market for Chinese audiovisual products is still relatively small, as is true of other Chinese cultural products, such as literature. The scarcity of data with regards translation reflects a common practice in audiovisual translation. As a general rule, the translator's name is never included in dubbed films -which account for the majority of films shown in Spanish movie theaters. In cinemas, at best one can read the name of the translator at the very end of the closing credits as long as the film has been subtitled. As for the rest of 
the formats, no information about the translator is available in VHS or DVD boxes and, needless to say, in pay per view TV or online available products.

This kind of information is neither registered on the official web page of the Spanish Ministry of Education, Culture, and Sport, nor by film distributors, film festivals, specialized webpages, film reviews, or in film presentation and credits sheets available at cinemas. Even though it is true that dubbing is a complex process that entails the involvement of many agents apart from the translator, the almost absolute lack of information provided about the translator both in the case of dubbed and subtitled films, reflects the translators' invisibility and the insignificant role they are perceived to have in the whole process. It must be said that this phenomenon is not exclusive to Chinese-Spanish audiovisual translation, as it is unfortunately the norm in audiovisual translation in general.

It is also worth mentioning that the Chinese-Spanish literary and audiovisual translation market in Spain is still rather small so it is relatively easy to be familiar with colleagues' background. In this sense, it is generally known that there are no professionals able to translate directly from Chinese dialects into Spanish or Catalan. Therefore, films including Chinese dialects, most probably have been translated directly from the script written in Standard Chinese or from the English subtitles, rather than using the original soundtrack, as should be the norm in audiovisual translation.

Finally, when it comes to translation modality, there is also a lack of data. Film festivals usually show subtitled films, while cinemas tend to opt for dubbing. However, although Spain is mainly a country where dubbing is king, non-commercial Chinese films are screened in cinemas targeting not mainstream audiences, but rather cinephiles fond of enjoying films with the original soundtrack and subtitles. This is also the case of home cinema, which usually offers dubbed versions, but sometimes also offers the possibility of hearing the original while viewing subtitles. 


\section{Conclusions}

This paper has offered a panoramic view of Chinese cinema in Spain through the lens of audiovisual translation. Like other Western countries, Spain has been exposed to two main types of Chinese films: martial art films and dramas, the former coming especially from Hong Kong and the latter from the Mainland. Other genres, such as animation or comedies, are still scarce and it remains to be seen whether the situation will change in the future. The most renowned directors are Zhang Yimou, followed by other Fifth and Sixth generation figures, several Hongkongese martial art movie directors, and a couple of Taiwanese names, such as Ang Lee or Hou Hsiao-hsien. However, even though the number of films and festivals that screen Chinese cinema has increased over time, the audience has not followed the same tendency. However, there is another positive trend, such as the reduction of the time between the release of films in Chinese and in Spanish. Taking into account the number of viewers, the most successful films are all martial arts movies first shown in the 1970s and 80s. One can conclude, then, that the image reflected by Chinese cinema in Spain is strongly related to martial arts and to a lesser extent to the historical and rural dramas made by Zhang Yimou, whose works have been deemed to be "orientalist" by some authors (Wang 1997; Lu 2005). The works that reach the Spanish market portray an oversimplified image of Chinese culture, since they draw the audience's attention to given historical periods and cultural practices, which fail to give an overview of China's true diversity and may reinforce existing prejudices about the Chinese.

Even though audiovisual translation is a crucial element in the introduction of Chinese films to a Spanish audience, our research has revealed that there is almost a complete lack of 
information as to the translators, the translation process, and translation modality. In our opinion this topic deserves more attention in order to analyze its possible impact on quality and, in turn, on reception, since such factors may affect the opinion the Spanish audience has of Chinese cinema.

Since the film industry is dynamic and every year there are new releases of Chinese films in Spain, our database will continue to grow with new entries and new information so that we can keep on offering an updated picture of Chinese cinema in Spain. Meanwhile, many important questions remain unanswered and should serve as a focus for future research. It would be interesting to further analyze different aspects of reception, starting with the audience profile, but also delving into the translation process. This could be done through focus groups, questionnaires and face-to-face interviews with regular viewers, film festival programmers, distribution companies, dubbing firms and professional translators. Another line for future research includes the analysis of paratexts through, not only discourse analysis, but also from the point of view of imagology, in order to study the creation or enhancement of cultural stereotypes through promotional images associated with films.

\section{Acknowledgments}

This article has been partially funded by the Generalitat de Catalunya (2017SGR113) and the Department of Translation, Interpreting and East Asian Studies (Universitat Autònoma de Barcelona). We would also like to thank Quim Crusellas, Enrique Garcelán, and San Sebastian, Malaga, Sitges and Gijon film festivals for providing us with information necessary to complete our database. 


\section{References}

Berry, Chris. 2008. "Cinema: From Foreign Import to Global Brand”. The Cambridge Companion to Modern Chinese Culture, ed. by Kam Louie, 297-317. Cambridge: CUP. doi:10.1017/CCOL9780521863223.015.

Beus, Yifen. 2008. "Far Away, So Close? Nation, Global Chinese Cinema and the Question of Identity”. Quarterly Review of Film and Videoerly Review of Film and Video 25 (4): $306-314$. doi:10.1080/10509200601105258.

Codó Martínez, Jordi. 2009. "Llegada y consumo de cines asiáticos en Occidente [Arrival and Consumption of Asian Cinemas in the West]". InterAsia Papers 10: 1-28.

Codó Martínez, Jordi. 2017. “El Cine Asiático en España 2016 [Asian Cinema in Spain 2016]". CineAsia. Anuario Vol. 2: 118-124.

Garcelán, Enrique. 2015. “Balance España 2013-2014. Asia en España: buscando un nuevo modelo [Asia in Spain: searching for a new model. 2013-2014 Yearbook]”. CineAsia. Anuario Vol 1: 99-102.

Gambier, Yves. 2009. "Challenges in Research on Audiovisual Translation”. In Translation Research Projects 2, ed. by Pym, Anthony; and Alexander Perekrestenko, 17-25. Tarragona: Intercultural Studies Group, Universitat Rovira i Virgili.

Lu, Sheldon H. 2005. "Chinese Film Culture at the End of the Century. The Case of Not One Less by Zhang Yimou”. In Chinese-Language Film. Historiography, Poetics, Politics, ed. by Emilie Yueh-yu Lu, Sheldon H.; Yeh, 120-37. Honolulu: University of Hawaii Press. 
Lu, Sheldon H.; Yeh, Emilie Yueh-yu. 2005. "Introduction: Mapping the Field of ChineseLanguage Cinema." In Chinese-Language Film. Historiography, Poetics, Politics, edited by Sheldon H. Lu; and Emilie Yueh-yu Yeh, 1-26. Honolulu: University of Hawaii Press.

MECD (Ministerio de Educación, Cultura y Deporte). 2017. "Publicaciones del ICAA e Informes [ICAA Documents and Reports]”. http://www.mecd.gob.es/cultura-mecd/areas-cultura/cine/informacion-servicios/in.html

Su, Wendy. 2010. "New Strategies of China's Film Industry as Soft Power”. Quarterly Review of Film and Video 18 (4): 451-71. doi:10.1080/10509200109361543

Sun, Shaoyi. 2016. "Chinese-Language Film or Chinese Cinema? Review of an Ongoing Debate in the Chinese Mainland". Journal of Chinese Cinemas 10 (1): 61-66. doi:10.1080/17508061.2016.1139803

Wang, Ning. 1997. “Orientalism versus Occidentalism?” New Literary History 28 (1): 57-67. Zhou, Yuxing. 2015. "Pursuing Soft Power through Cinema: Censorship and Double Standards in Mainland China”. Journal of Chinese Cinemas 9 (3): 239-252. doi:10.1080/17508061.2015.1049878

Zhu, Ying. 2001. "Cinematic Modernization and Chinese Cinema's First Art Wave”. Quarterly Review of Film and Video 18 (4): 451-471. doi:10.1080/10509200109361543

\section{Résumé}


La traduction audiovisuelle est devenue l'un des principaux moyens de communication entre les cultures. Bien que le nombre de films chinois qui atteignent le public espagnol soit plutôt limité, le cinéma reste un outil très puissant pour combler le fossé entre ces deux cultures. Cet article vise à donner un aperçu de la situation du cinéma chinois en Espagne, à travers la traduction audiovisuelle. Pour ce faire, nous avons créé une base de données de 500 films chinois, traduits en espagnol. Nous avons recueilli, pour chaque film, différents types d'informations organisées en trois blocs : premièrement, les données concernant le film source en chinois ; deuxièmement, les données sur le film traduit; et enfin, des informations sur les paratextes relatifs au film en chinois, espagnol et anglais. Grâce à une analyse quantitative et qualitative de nos données, nous présentons les principales tendances de la traduction audiovisuelle du chinois en espagnol, depuis le milieu des années 70 jusqu'à aujourd'hui. Nos résultats identifient les réalisateurs chinois les plus populaires et les principaux genres et modalités de traduction. Nous soulignons le rôle du traducteur et l'importance de la médiation linguistique et, enfin, nous insistons sur le rôle significatif des canaux de distribution, en particulier, des festivals de cinéma. Cet article vise à combler une lacune en ce qui concerne la recherche en traduction audiovisuelle en tant qu'échange interculturel entre la Chine et l'Espagne.

Mots-clés : cinéma chinois, traduction du chinois en espagnol, traduction audiovisuelle, réception

\section{Address for correspondence}


Helena Casas-Tost

Universitat Autònoma de Barcelona

Departament de Traducció i Interpretació i d'Estudis de l'Àsia Oriental

Transmedia Catalonia and TXICC Research Group

Bellaterra (Cerdanyola del Vallès), 08193, Spain

Helena.Casas@uab.cat,

\section{Co-author information}

\section{Sara Rovira-Esteva}

Sara.Rovira@uab.cat 